\section{Boils and skin infections}

\section{What are boils?}

A boil is an infection of the skin, usually caused by Staphylococcus aureus bacteria (commonly known as 'golden staph'). Many healthy people carry these bacteria on their skin or in their nose without getting an infection. Boils occur when bacteria penetrate broken skin and cause tender, swollen sores that are full of pus.

Other skin infections such as impetigo may be caused by staph bacteria. Impetigo - commonly known as school sores as they affect school-age children - are small blisters or flat, crusty sores on the skin. When the blisters rupture they release a yellow fluid and develop honey-coloured crusts.

\section{How are they spread?}

Boils and other skin infections are spread between people by:

- squeezing, scratching or contact with an infected area

- using unwashed clothes, towels or bed sheets that have been used by a person with a skin infection

- using grooming items (e.g. nail scissors, tweezers, razors and toothbrushes) that have been used by a person with a skin infection

- not washing hands carefully.

\section{How is the spread prevented?}

- Hand washing is important to prevent the spread of boils and skin infections. Hands should be thoroughly washed with soap and running water for 10-15 seconds before and after touching or dressing an infected area, before handling or eating food, after going to the toilet, after blowing your nose and after touching or handling unwashed clothing or linen.

- Keep cuts, scrapes and boils clean and covered to avoid infection.

- Do not share personal items (e.g. clothes, towels or bed sheets) or grooming items (e.g. nail scissors, tweezers, razors and toothbrushes). If you share a bed with someone, keep sores or wounds covered overnight.

- Wash bed linen and clothing regularly.

\section{How are they diagnosed?}

Most skin infections are diagnosed on the basis of their appearance and the presence of any related symptoms (e.g. fever). Your doctor may take swabs or samples from boils, wounds or other sites of infection to identify the bacteria responsible.

\section{How are they treated?}

- Bathe the boil or sore with soap and water or a saltwater mixture.

- Apply a hot compress to encourage the boil to come to a head.

- Keep boils and other skin infections covered and change dressings regularly.

- Do not squeeze boils or abscesses - drainage should only be performed by a doctor, trained nurse or health worker.

- In some circumstances, infections may require treatment with antibiotics.

- If the sores spread or get worse, or if the person becomes unwell with fever, consult a doctor for further advice. A doctor may prescribe antibiotics (by mouth or as an ointment). It is important to follow the recommended treatment and finish the full course of antibiotics.

\section{What is the public health response?}

Boils and skin infections are not notifiable in NSW. Public health units can advise on the control of outbreaks.

For more information, please contact your doctor, local public health unit or community health centre.

This factsheet is available at: http://www.health.nsw.gov.au/ factsheets/infectious/boils_and_skininfect.html 